\title{
A Novel Genus of Actinobacterial Tectiviridae
}

\author{
Steven M. Caruso ${ }^{1} \mathbb{D}$, Tagide N. deCarvalho ${ }^{2,3}{ }^{1}$, Anthony Huynh ${ }^{1}$, George Morcos ${ }^{1}$, \\ Nansen Kuo ${ }^{1}$, Shabnam Parsa ${ }^{1}$ and Ivan Erill ${ }^{1, *(D)}$ \\ 1 Department of Biological Sciences, University of Maryland Baltimore County (UMBC), Baltimore, MD 21250, \\ USA; scaruso@umbc.edu (S.M.C.); ST33486@umbc.edu (A.H.); gmorcos1@umbc.edu (G.M.); \\ nansen1@umbc.edu (N.K.); shab2@umbc.edu (S.P.) \\ 2 Keith R. Porter Imaging Facility, University of Maryland Baltimore County (UMBC), \\ Baltimore, MD 21250, USA; tagided@umbc.edu \\ 3 College of Natural and Mathematical Sciences, University of Maryland Baltimore County (UMBC), \\ Baltimore, MD 21250, USA \\ * Correspondence: erill@umbc.edu; Tel.: +1-410-455-2470
}

Received: 27 October 2019; Accepted: 4 December 2019; Published: 7 December 2019

\begin{abstract}
Streptomyces phages WheeHeim and Forthebois are two novel members of the Tectiviridae family. These phages were isolated on cultures of the plant pathogen Streptomyces scabiei, known for its worldwide economic impact on potato crops. Transmission electron microscopy showed viral particles with double-layered icosahedral capsids, and frequent instances of protruding nanotubes harboring a collar-like structure. Mass-spectrometry confirmed the presence of lipids in the virion, and serial purification of colonies from turbid plaques and immunity testing revealed that both phages are temperate. Streptomyces phages WheeHeim and Forthebois have linear dsDNA chromosomes $(18,266 \mathrm{bp}$ and 18,251 bp long, respectively) with the characteristic two-segment architecture of the Tectiviridae. Both genomes encode homologs of the canonical tectiviral proteins (major capsid protein, packaging ATPase and DNA polymerase), as well as PRD1-type virion-associated transglycosylase and membrane DNA delivery proteins. Comparative genomics and phylogenetic analyses firmly establish that these two phages, together with Rhodococcus phage Toil, form a new genus within the Tectiviridae, which we have tentatively named Deltatectivirus. The identification of a cohesive clade of Actinobacteria-infecting tectiviruses with conserved genome structure but with scant sequence similarity to members of other tectiviral genera confirms that the Tectiviridae are an ancient lineage infecting a broad range of bacterial hosts.
\end{abstract}

Keywords: tectivirus; Streptomyces; actinobacteria; pathogen; plant; lipid membrane; capsid protein; potato scab

\section{Introduction}

The Tectiviridae are a family of tail-less double-stranded DNA (dsDNA) phages characterized by an internal protein-rich lipid membrane enclosed within a non-enveloped icosahedral proteinaceous capsid [1,2]. Tectiviruses bind to the host cell surface via receptor binding proteins integrated into the spikes that protrude from each capsid vertex [3]. After adsorbing to the host cell, the tectiviral membrane vesicle is reorganized to generate a tubular structure. This nanotube protrudes from one of the capsid vertices in order to inject the viral DNA [4,5]. DNA injection is presumed to be driven initially by pressure build-up during DNA packaging, and is contingent on the formation of the nanotube and the consequent reduction in membrane vesicle volume $[5,6]$. Tectiviruses are substantially underrepresented among known prokaryotic viruses, but together with other lipid membrane-containing viruses they have been shown to form an ancient and widely distributed lineage of viruses with important implications for prokaryotic biology and evolution [2,7]. The tectiviral 
lineage is characterized primarily by the double jelly-roll major capsid protein (DJR MCP) that makes up the viral capsid, and the use of a specialized FtsK-HerA superfamily ATPase for DNA packaging [8]. The Tectiviridae family is currently divided into three main genera [9]. The Alphatectivirus genus was defined based on the type species Pseudomonas virus PRD1 and comprises a group of closely related virulent phages infecting a variety of Gammaproteobacteria hosts [1]. These include Enterobacteria phage PR4 and Enterobacteria phage PR3 Enterobacteria phage PR772 isolated, respectively, on Escherichia coli and Proteus mirabilis [10], as well as Enterobacteria phage L17. Extensive work on Pseudomonas virus PRD1 has determined many of the morphological and genetic features used to define the family Tectiviridae [11].The Betatectivirus genus is exemplified by the Bacillus virus Bam35 type species. It encompasses a broader group of temperate phages infecting members of several Firmicutes genera. These phages include Bacillus phage p GIL01 and Bacillus phage p GIL16, infecting Bacillus cereus group hosts [12], as well as Bacillus virus AP50 and Bacillus phage Wip1, capable of infecting the bacterial pathogen Bacillus anthracis [13,14]. Members of the Betatectivirus genus replicate independently of the host chromosome as linear plasmids and regulate transition to a lytic lifestyle via the host SOS transcription repressor LexA [15]. The Gammatectivirus genus contains only one known member, Gluconobacter phage GC1, which is also temperate and infects the Alphaproteobacterium Gluconobacter cerinus [16].

Rhodococcus phage Toil, a phage infecting Rhodococcus opacus, was recently characterized and reported as the first tectivirus capable of infecting Actinobacteria [17]. Here we report the isolation, characterization and genome sequencing of two new tectiviruses as part of an ongoing effort to characterize phages infecting the causative agent of potato scab, Streptomyces scabiei, within the Science Education Alliance-Phage Hunters Advancing Genomics and Evolutionary Science (SEA-PHAGES) and STEM BUILD at UMBC programs [18-21]. S. scabiei is best known for its worldwide economic impact on potato crops [22,23], but it has a broad host range that encompasses carrot and radish taproot crops, as well as many other dicots and monocots [22]. This plant pathogen produces the phytotoxin thaxtomin A, which inhibits cellulose synthesis, leading to the signature scab symptoms [24]. Because there is no known mechanism for effective disease suppression after initial infestation, multiple management strategies and approaches have been explored for the control of S. scabiei [22], including the effective use of virulent bacteriophages [25]. The novel tectiviruses reported in this work (Streptomyces phage WheeHeim and Streptomyces phage Forthebois) were isolated on S. scabiei and expand the existing collection of Caudovirales phages active against this important pathogen [21,25-28]. These two phages share morphological features, genomic structure and moderate sequence similarity with Rhodococcus phage Toil. Phylogenetic analyses clearly establish that Rhodococcus phage Toil and Streptomyces phages WheeHeim and Forthebois collectively define a monophyletic group of phages infecting Actinobacteria within the Tectiviridae family. We propose that, given their distinctive features, these three bacteriophages be considered the founding members of a novel Tectiviridae genus, tentatively named Deltatectivirus.

\section{Materials and Methods}

\subsection{Isolation and Purification of Phages Infecting Streptomyces Scabiei}

Bacterial strains and phages used in this study are listed in Table S1. Streptomyces cultures were grown in nutrient broth (BD Difco) supplemented with $10 \mathrm{mM} \mathrm{MgCl} 2,8 \mathrm{mM} \mathrm{Ca}\left(\mathrm{NO}_{3}\right)_{2}, 0.5 \%$ glucose $\left(\mathrm{NB}^{+}\right)$, and $0.05 \%$ polyethylene glycol (PEG 8000) at $30{ }^{\circ} \mathrm{C}$ for at least $48 \mathrm{~h}$ with shaking prior to use [29]. Streptomyces phages WheeHeim and Forthebois were extracted from soil samples with phage buffer (10 mM Tris pH 7.5, $\left.10 \mathrm{mM} \mathrm{MgSO}_{4}, 1 \mathrm{mM} \mathrm{CaCl}_{2}, 68.5 \mathrm{mM} \mathrm{NaCl}\right)$ and filtered through a 0.22 $\mu \mathrm{m}$ filter. $500 \mu \mathrm{L}$ of the filtrate was added to $250 \mu \mathrm{L}$ of a $48 \mathrm{~h}$ culture of Streptomyces scabiei RL-34 (ATCC 49173), incubated $10 \mathrm{~min}$ at room temperature, combined with $4 \mathrm{~mL}$ of tryptic soy soft agar (BD), overlaid on nutrient agar (BD Difco) supplemented with $\left.10 \mathrm{mM} \mathrm{MgCl}_{2}, 8 \mathrm{mM} \mathrm{Ca} \mathrm{NO}_{3}\right)_{2}$, and $0.5 \%$ glucose $\left(\mathrm{NA}^{+}\right)$, and incubated for 24 to $48 \mathrm{~h}$ at $30^{\circ} \mathrm{C}$. Phages were plaque purified on lawns of $S$. scabiei as previously described [30]. 


\subsection{Production of High-Titres Lysates and Phage Concentration}

Crude stock and $\mathrm{CsCl}$ purified lysates were produced on $\mathrm{NA}^{+}$solid media using protocols described previously [30]. After a minimum of three rounds of plaque purification, plaques were picked into phage buffer and diluted to produce plates with near-confluent lysis after infection of $S$. scabiei. Plates were then covered with $8 \mathrm{~mL}$ phage buffer, and incubated overnight at $4{ }^{\circ} \mathrm{C}$. The lysate was centrifuged for $20 \mathrm{~min}$ at $2500 \times \mathrm{g}$ and then passed through a $0.22 \mu \mathrm{m}$ filter. For $\mathrm{CsCl}$ purification, $300 \mathrm{~mL}$ filtered crude lysate at $10^{9} \mathrm{pfu} / \mathrm{mL}$ was produced, concentrated by incubation with PEG 8000, and purified by two rounds of banding by $\mathrm{CsCl}$ ultracentrifugation [30].

\subsection{Host Range Analysis}

The host range of each phage was tested by spotting diluted crude lysate on lawns of Streptomyces spp. [31]. Cultures were obtained from the Agricultural Research Service (ARS, https://nrrl.ncaur. usda.gov/). $\mathrm{NA}^{+}$plates were inoculated with $250 \mu \mathrm{L}$ of $48 \mathrm{~h}$ cultures of Streptomyces azureus NRRL B-2655, Streptomyces bobili NRRL B-1338, Streptomyces bottropensis ISP-5262, Streptomyces coelicolor subsp. coelicolor NRRL B-2812, Streptomyces coelicolor subsp. coelicolor A3(2) NRRL B-16638, Streptomyces diastatochromogenes NRRL ISP-5449, Streptomyces griseus subsp. griseus NRRL B-2682, Streptomyces mirabilis NRRL B-2400, Streptomyces neyagawaensis ISP 5588, Streptomyces xanthochromogenes NRRL B-5410, and the control host $S$. scabiei in trypticase soy soft agar (Table S1). Once set, $5 \mu \mathrm{L}$ aliquots of serially diluted lysate were spotted on each plate, then incubated at $30^{\circ} \mathrm{C}$ for up to $96 \mathrm{~h}$. Resulting plaques were re-purified on the test host to confirm phage amplification and exclude killing from without. Efficiency of plating (EOP) was calculated as the titer determined on the test species divided by the titer determined on the isolation host.

\subsection{Isolation of Lysogens and Immunity Testing}

Putative WheeHeim and Forthebois lysogens were isolated by spotting diluted crude lysate on $\mathrm{NA}^{+}$ overlaid with $250 \mu \mathrm{L}$ of a $48 \mathrm{~h}$ culture of S. scabiei RL-34 in trypticase soy soft agar incubated for $96 \mathrm{~h}$ at $30{ }^{\circ} \mathrm{C}$. Cells were isolated from a zone of clearing and streak purified three times. A resulting colony was then used to inoculate $3 \mathrm{~mL} \mathrm{NB}^{+}$with $0.05 \%$ polyethylene glycol (PEG 8000) and incubated for $48 \mathrm{~h}$ at $30^{\circ} \mathrm{C}$. To test for the presence of released phage, $500 \mu \mathrm{L}$ of the culture was centrifuged for $1 \mathrm{~min}$ at $11,700 \times g$, and the supernatant was serially diluted and $3 \mu \mathrm{L}$ spotted on $\mathrm{NA}^{+}$overlaid with $250 \mu \mathrm{L}$ of a $48 \mathrm{~h}$ culture of $S$. scabiei RL-34 in trypticase soy soft agar incubated for $48 \mathrm{~h}$ at $30^{\circ} \mathrm{C}$. To test for superinfection immunity, crude lysate stocks of Streptomyces phages Scap1 [21], Forthebois, WheeHeim, and S. scabiei (Forthebois) lysogen supernatant were serially diluted and $3 \mu \mathrm{L}$ spotted on $\mathrm{NA}^{+}$overlaid with $250 \mu \mathrm{L}$ of a culture of S. scabiei RL-34 (Forthebois) lysogens in trypticase soy soft agar incubated for $96 \mathrm{~h}$ at $30^{\circ} \mathrm{C}$ with daily examination.

\subsection{Electron Microscopy}

$10 \mu \mathrm{L}$ phage lysate was placed on a 200 mesh formvar-covered and carbon-coated copper grids (EMS) and allowed to set for $1 \mathrm{~min}$, briefly rinsed with ultra-pure water, then stained with $2 \%$ uranyl acetate for 2 min. Phages were imaged on an Morgagni M268 Transmission Electron Microscope (FEI, Hillsboro, IL, USA) equipped with an Orius CCD camera (Gatan Inc., Pleasanton, CA, USA).

\subsection{Extraction of Phage DNA}

Five $\mu \mathrm{L}$ nuclease mix $(0.25 \mathrm{mg} / \mathrm{mL}$ DNase I, $0.25 \mathrm{mg} / \mathrm{mL}$ RNase A, $50 \%$ glycerol, $150 \mathrm{mM} \mathrm{NaCl})$ was added to $1 \mathrm{~mL}$ crude lysate, mixed gently by inversion, and incubated at $37^{\circ} \mathrm{C}$ for $10 \mathrm{~min}$. The nuclease was then inactivated and phage gDNA isolated by the addition of $15 \mu \mathrm{L} 0.5 \mathrm{M}$ EDTA, 50 $\mu \mathrm{L} 10 \%$ SDS, and $0.5 \mu \mathrm{L} 20 \mathrm{mg} / \mathrm{mL}$ Proteinase $\mathrm{K}$ followed by washing and concentration using a Wizard DNA clean-up system (Promega, Madison, WI, USA). DNA was eluted in $\mathrm{ddH}_{2} \mathrm{O}$ and quantified by Thermo Scientific nanodrop (Waltham, MA, USA) and gel electrophoresis. 


\subsection{DNA Sequencing}

Sequencing was performed by the NC State Genomic Sciences Laboratory to approximately $10,000 \times$ coverage with the MiSeq platform (Illumina, San Diego, CA, USA). Assembly was performed using the CLC Genomics Workbench NGS de novo assembler (v6) with default settings and minimum contig length of $500 \mathrm{bp}$. Ends were determined from analysis of Illumina single-end sequencing reads by the Pittsburgh Bacteriophage Institute. Reads were examined for the presence of inverted repeats and for their presence of reads extending across contig ends.

\subsection{Genome Annotation and Analysis}

Genome annotation was completed using DNA Master (v5.23.3) [32] with default settings. Automated gene calls were independently assessed by two different annotators and further validated with complemented ARAGORN (v1.2.38), tRNAscan (v2.0) and GeneMarkS (v3.25) [33-35]. Functional annotations were performed using the NCBI BLASTP and HHPred services with default parameters following the SEA-PHAGES annotation guidelines (maximum BLASTP $e$-value: $10^{-7}$, minimum HHpred probability: 90\%) and independently assessed by at least two annotators [36-38]. A collection of experimentally reported LexA-binding sites in Actinobacteria was downloaded from the CollecTF database [39]. These sites were used to scan the Streptomyces phages WheeHeim and Forthebois genome sequences using XFITOM [40]. Pair-wise analyses of genome-wide nucleotide and amino acid similarity were computed using Average Amino acid Identity (AAI) and Average Nucleotide Identity (ANI) calculators [41].

\subsection{Mass Spectroscopy}

$\mathrm{CsCl}$ purified samples of Streptomyces phage WheeHeim and Mycobacterium phage Rosebush [42] were dialyzed into water-methanol (50:50 v/v) with $0.1 \%$ Formic acid using a $3.5 \mathrm{~K}$ MWCO Pierce Slide-A-Lyzer MINI Dialysis Device (Thermo Scientific, Waltham, MA, USA). Viral particles were analyzed by an Autoflex MALDI-TOF/MS (Bruker, Billerica, MA, USA) in negative mode [43] using 2,5-Dihydroxybenzoic acid (DHB) as the matrix.

\subsection{Ortholog Detection}

Orthologous protein sequences among Rhodococcus phage Toil and Streptomyces phages WheeHeim and Forthebois were determined as best-reciprocal BLAST hits with an $e$-value cutoff of $1 \times 10^{-5}$. To detect more distant orthologs, Hidden Markov Models (HMM) were downloaded for the PFAM (31.0), COG (2014) and eggNOG (bactNOG and Viruses; 4.5.1) databases [44-47] and searched with phage proteins using hmmscan [48] with an $e$-value cutoff of $1 \times 10^{-5}$. Pre-compiled multiple sequence alignments for signature protein families present in DJR MCP-containing viruses were obtained from [8], processed into HMM with hmmbuild and used to search phage protein files with hmmsearch and a $1 \times 10^{-10} e$-value cutoff.

\subsection{Phylogenetic Methods}

Nucleotide and protein sequences for Tectiviridae phages were obtained from the NCBI GenBank and RefSeq databases [49]. Protein sequences were aligned using M-COFFEE with default parameters [50], and the resulting alignments were pruned with Gblocks with less astringent selection options [51]. Pruned alignments were used for Bayesian phylogenetic inference with MrBayes 3.1 applying a mixed four-category Gamma distributed rate model plus proportion of invariable sites model (invgamma) [52]. Two Metropolis-Coupled Markov Chain Monte Carlo runs with four independent chains were carried out for $5 \times 10^{5}$ generations. The resulting consensus trees were plotted with Dendroscope [53]. A genome-based phylogeny was generated with the VICTOR webservice [54]. Intergenomic protein sequence distances were computed with 100 pseudo-bootstrap replicates using the Genome-BLAST Distance Phylogeny (GBDP) method optimized (distance formula 
$d_{6}$ ) for prokaryotic viruses $[54,55]$, and a minimum evolution tree was computed with FASTME on the resulting intergenomic distances [56].

\section{Results}

\subsection{Isolation, Host Range and Morphological Characterization of Streptomyces Phages WheeHeim} and Forthebois

Streptomyces phages WheeHeim and Forthebois were isolated on a pure culture of S. scabiei RL-34 from soil samples collected, respectively, in Saigon (Vietnam) and Halethorpe (MD, USA) by undergraduate students participating in the SEA-PHAGES program. S. scabiei RL-34 is the type strain for the causative agent of potato scab, and forms heavily branched sporulating aerial mycelia in agar media [57]. The SEA-PHAGES program has to date isolated 56 additional phages capable of infecting S. scabiei RL-34. These phages all display caudoviral morphologies and a lytic lifestyle [58]. Streptomyces phages WheeHeim and Forthebois, in contrast, generated turbid, circular plaques with 2-5 mm diameter on lawns of S. scabiei RL-34 after $48 \mathrm{~h}$ at $30^{\circ} \mathrm{C}$. The host range of both phages was assessed by spotting diluted crude lysate on lawns of ten additional Streptomyces species. Both phages displayed a fairly limited host range among the tested strains, being able to infect only $S$. mirabilis NRRL B-2400 at an efficiency-of-plating (EOP) of approximately 20, in addition to the isolation host S. scabiei RL-34 (Table S2). Phages infecting only S. mirabilis and S. scabiei among this group of tested strains have been reported previously for Siphoviridae phages infecting S. scabiei [21], suggesting that S. mirabilis and S. scabiei share important properties for phage infection that are absent in the closely related S. diastatochromogenes [59].

Transmission electron microscopy (TEM) images of WheeHeim and Forthebois revealed viral particles with six-sided, double-layered phage capsids (Figure 1a,c; black arrows) with an average circumscribed diameter of $65.5 \mathrm{~nm}(\mathrm{SD}=4.4, n=20)$ and $64.4 \mathrm{~nm}(\mathrm{SD}=4.5, n=20)$, respectively, consistent with the two-dimensional projection of an icosahedral structure. Several virion particles demonstrated protruding nanotubes with a respective average length of $37.0 \mathrm{~nm}$ (WheeHeim; $\mathrm{SD}=4.4$, $n=13$ ) and $41.6 \mathrm{~nm}$ (Forthebois; $\mathrm{SD}=8.4, n=170$ ). Examination of hundreds of virions revealed that these tubular structures were present on $3-7 \%$ of virions in the crude lysate (WheeHeim $n=6 / 200$; Forthebois $n=14 / 186$ ), protruding in all cases from an apparent capsid vertex, consistent with previous reports of tectiviral particles [6,60-62] (Figure 1b,d; white arrows). Together, the presence of a double-layered membrane and of protruding nanotubes strongly suggested that these bacteriophages belonged to the Tectiviridae family. In virions with protruding tubular structures, a reduction of $\sim 4.0 \%$ in capsid size was observed, consistent with previous reports [6], and a collar-like structure surrounding the base of the tube could also be discerned (Figure 1b,d and Figure S1). Tail collar structures have been described in members of all families of Caudovirales [63-65], but had to date not been reported in the Tectiviridae. A re-examination of previously reported tectiviral nanotube images suggests that these structures may be present in other Tectiviridae [61,62], and may therefore be a common feature of tectiviral particles with protruding nanotubes. 

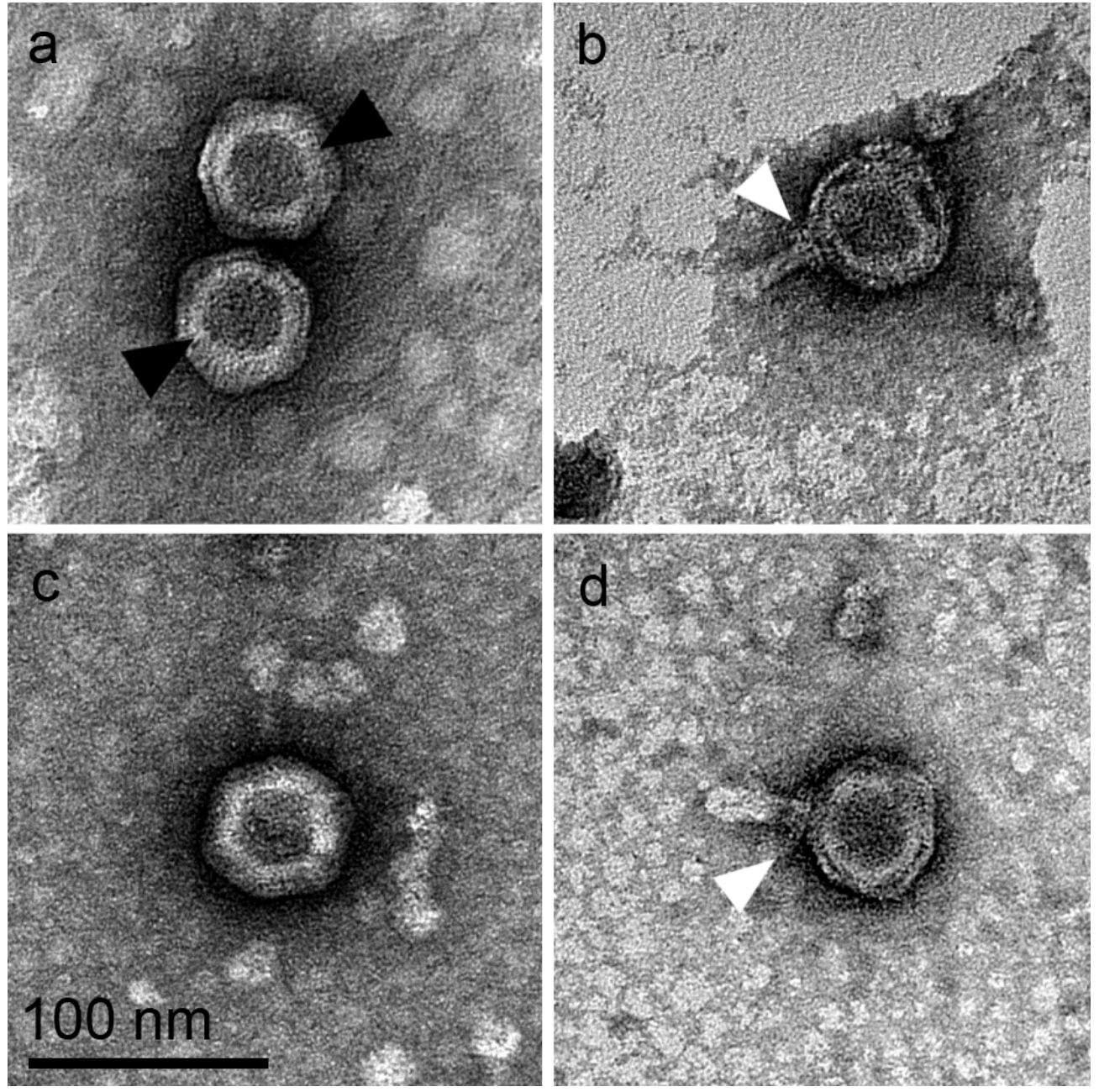

Figure 1. Representative TEM images of (a) CsCl-purified WheeHeim; (b) WheeHeim with nanotube from crude lysate; (c) Forthebois from crude lysate; (d) Forthebois with nanotube from crude lysate. Black arrowheads indicate lipid membrane. White arrowheads indicate collar-like structure.

Scale bar $=100 \mathrm{~nm}$ for all panels.

\subsection{Genome Sequencing and Annotation}

To gain further insight into Streptomyces phages WheeHeim and Forthebois, DNA from both phages was extracted and sequenced on an Illumina MiSeq Next Generation Sequencer. The chromosomes of both phages were determined by read analysis to consist of a linear dsDNA molecule of 18,266 bp (WheeHeim) and 18,251 bp (Forthebois). Both phages presented 24 bp inverted repeats at their ends, with no reads extending past the contig ends. This arrangement is reminiscent of $\varphi 29$-like phages, which are typically packaged with covalently-linked terminal proteins [66]. In spite of their distant collection sites, the WheeHeim and Forthebois chromosomes present an average nucleotide identity (ANI) of $88.5 \%$ [67] and a very similar GC content (54.6\% and 53.6\%, respectively). The WheeHeim and Forthebois chromosomes contain 36 protein coding genes, as well as a tRNA-Asn gene. Function could be assigned with confidence to only half of the genes (Table 1). Both genomes present the same overall two-segment arrangement, with a first segment of genes in the reverse strand and a second, larger one, in the forward strand. This arrangement is reminiscent of the one reported recently for Rhodococcus phage Toil [17]. The first segment encompasses genes coding for a DNA polymerase, a single-stranded DNA binding protein and a homolog of the nucleotide pyrophosphohydrolase MazG [68]. The second, larger segment in the forward strand contains structural genes and genes involved in cell lysis, such as, respectively, a homolog of the PRD1 major capsid protein and a LysM-like Endolysin [69]. 
This segment also encompasses two homologs of the PRD1 P34 membrane DNA delivery protein, a hydrolase and a glycosyltransferase. The identification of two homologs of Pseudomonas virus PRD1 proteins, and the similarity of the two-segment genome organization to that reported for Rhodococcus phage Toil, supported the morphological inference that Streptomyces phages WheeHeim and Forthebois are tectiviruses.

Table 1. Genes with functionally annotated products in Streptomyces phages WheeHeim and Forthebois.

\begin{tabular}{|c|c|c|}
\hline Locus Tag & Locus Tag & Product ${ }^{1}$ \\
\hline SEA_WHEEHEIM_3 & SEA_FORTHEBOIS_3 & $\begin{array}{l}\text { MazG-like nucleotide } \\
\text { pyrophosphohydrolase }\end{array}$ \\
\hline SEA_WHEEHEIM_4 & SEA_FORTHEBOIS_4 & membrane protein \\
\hline SEA_WHEEHEIM_7 & SEA_FORTHEBOIS_7 & tRNA-Asn \\
\hline SEA_WHEEHEIM_11 & SEA_FORTHEBOIS_11 & DNA polymerase \\
\hline SEA_WHEEHEIM_13 & SEA_FORTHEBOIS_13 & ssDNA binding protein \\
\hline SEA_WHEEHEIM_16 & SEA_FORTHEBOIS_16 & hydrolase \\
\hline SEA_WHEEHEIM_18 & SEA_FORTHEBOIS_18 & major capsid protein \\
\hline SEA_WHEEHEIM_19 & SEA_FORTHEBOIS_19 & membrane protein \\
\hline SEA_WHEEHEIM_20 & SEA_FORTHEBOIS_20 & membrane protein \\
\hline SEA_WHEEHEIM_21 & SEA_FORTHEBOIS_21 & membrane protein \\
\hline SEA_WHEEHEIM_22 & SEA_FORTHEBOIS_22 & membrane DNA delivery protein \\
\hline SEA_WHEEHEIM_26 & SEA_FORTHEBOIS_26 & glycosyltransferase \\
\hline SEA_WHEEHEIM_27 & SEA_FORTHEBOIS_27 & membrane protein \\
\hline SEA_WHEEHEIM_28 & SEA_FORTHEBOIS_28 & membrane DNA delivery protein \\
\hline SEA_WHEEHEIM_31 & SEA_FORTHEBOIS_30 & peptidase \\
\hline SEA_WHEEHEIM_32 & SEA_FORTHEBOIS_31 & membrane protein \\
\hline SEA_WHEEHEIM_36 & SEA_FORTHEBOIS_35 & LysM-like endolysin \\
\hline
\end{tabular}

${ }^{1}$ Product functions annotated according to SEA-PHAGES functional annotation standards.

\subsection{Virion Stability, Lifestyle and Determination of the Membrane Composition}

The presence of an internal protein-rich lipid membrane is a hallmark of tectiviruses. To ascertain whether the double-layered phage capsids observed in TEM images corresponded to an internal lipid membrane enclosed within a non-enveloped capsid, $\mathrm{CsCl}$ purified samples of Streptomyces phage WheeHeim were analyzed by MALDI-TOF, using Mycobacterium phage Rosebush, a siphovirus, as a control (Figure 2) [42]. The WheeHeim spectrum is enriched for peaks likely corresponding to phosphatidylglycerol (PG; $m / z$ 845) and phosphatidylethanolamine (PE; $m / z$ 760), known to be major components of the lipid membrane in tectiviruses infecting both Gram-positive and Gram-negative hosts $[43,70,71]$. Furthermore, the WheeHeim spectrum also presents multiple peaks in the $m / z$ 1300-1500 range, corresponding to PG dimers (cardiolipins; CL). These peaks, and specifically the center peak at $m / z$ 1348, match those reported for Pseudomonas virus PRD1 [43]. Overall, the WheeHeim spectrum, modulated by its host lipid species, is consistent with the lipid composition of previously reported tectiviruses [71,72].

Streptomyces phages WheeHeim and Forthebois presented turbid plaques, which can be indicative of lysogeny. Most tectiviruses infecting Gram-positive hosts have been shown to be temperate [15,73], thus we attempted to isolate lysogens by isolating and serially purifying cells that survived phage infection, then testing for the presence of spontaneous release of phage. Our results show that, after purification, S. scabiei cells isolated from apparent colonies within turbid plaques were able to induce plaque formation on a S. scabiei RL-34 lawn, indicating that they are releasing phage (Figure 3a and Figure S2).

Furthermore, lawns of these putative S. scabiei lysogens could be infected by Streptomyces phage Scap1 (a Siphoviridae infecting S. scabiei [21]), but not by WheeHeim or Forthebois, indicating that lysogens exhibited superinfection exclusion (Figure 3b). Bacillus-infecting tectiviruses have been reported to use the host's LexA repressor to activate the lytic cycle by binding at multiple promoters $[15,74]$, but no putative LexA-binding sites could be detected on genome-wide scans of Streptomyces phages 
WheeHeim and Forthebois genome sequences. Similarly, none of the lysogeny associated proteins from Bacillus-infecting tectiviruses could be detected in Streptomyces phages WheeHeim and Forthebois. These results suggest that Streptomyces phages WheeHeim and Forthebois are temperate phages. Alternatively, they might be plasmid-phages with an unusually long carrier state capable of exhibiting superinfection exclusion after more than 100 generations [75,76]. In both cases, the absence of homologs for conventional lysogeny-related genes or plasmid-associated rep genes puts forward the hypothesis that these phages might utilize a novel mechanism for determining phage replication and cell fate.

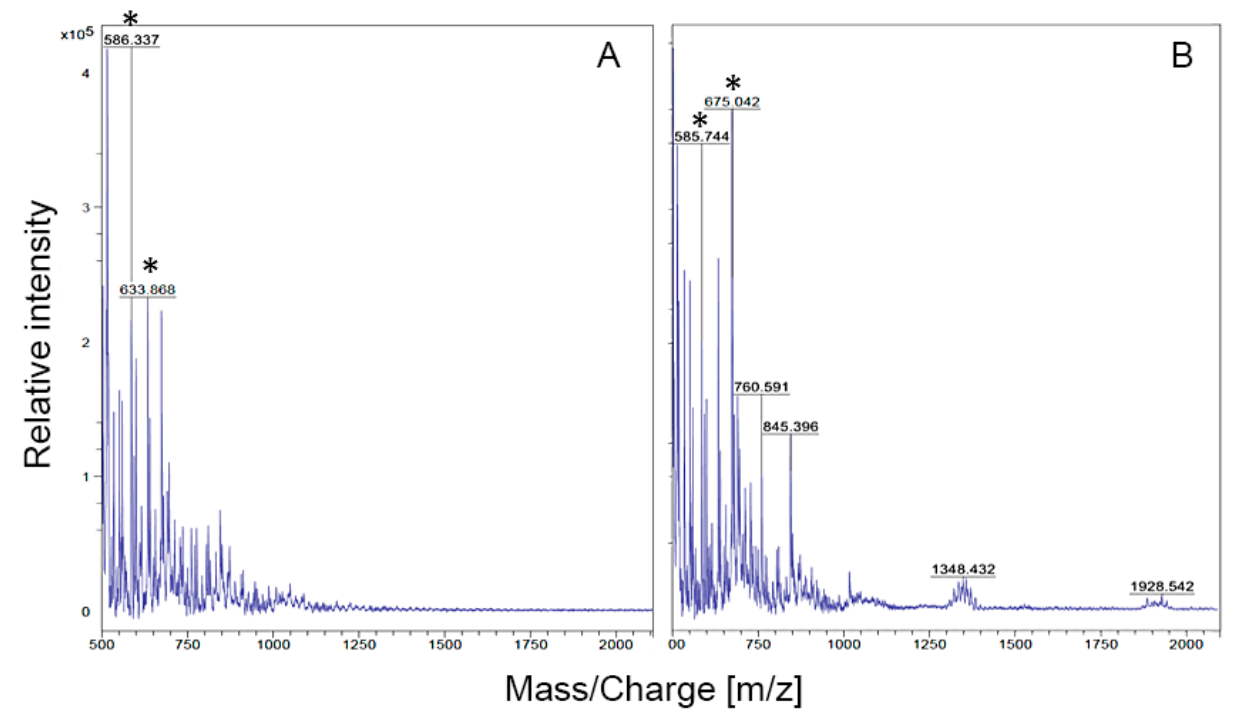

Figure 2. MALDI-TOF spectra for (A) Mycobacterium phage Rosebush and (B) Streptomyces phage WheeHeim. Asterisks denote DHB (2,5-Dihydroxybenzoic acid) matrix peaks. $\mathrm{m} / \mathrm{z}$ denotes mass $(\mathrm{m})$ to charge (z) ratio.

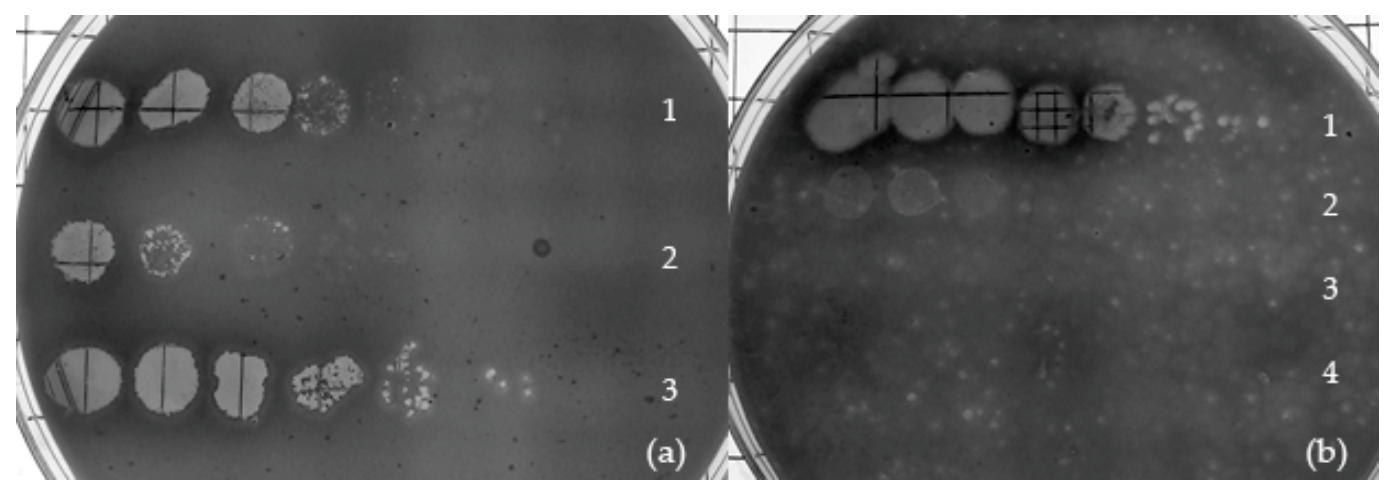

Figure 3. Lysogen isolation and testing. (a) Liquid phage release from WheeHeim lysogens. Serially diluted stock Streptomyces phage WheeHeim (row 1), streak purified S. scabiei (WheeHeim) lysogen supernatant (row 2), and stock Streptomyces phage Forthebois (row 3) spotted on $\mathrm{NA}^{+}$overlayed with S. scabiei RL-34 after $48 \mathrm{~h}$ at $30^{\circ} \mathrm{C}$. (b) Superinfection immunity test of S. scabiei (Forthebois) lysogen. Serially diluted crude lysate stocks of Streptomyces phage Scap1 (row 1) Forthebois (row 2), WheeHeim (row 3), and S. scabiei (Forthebois) lysogen supernatant (row 4) spotted on $\mathrm{NA}^{+}$overlayed with S. scabiei (Forthebois) lysogen after $48 \mathrm{~h}$ at $30^{\circ} \mathrm{C}$.

\subsection{Comparative Genomics and Phylogenetic Analysis}

Genomic analyses of previously reported Tectiviridae phages have established the family-wide conservation of three major proteins: a double jelly-roll major capsid protein (DJR MCP), a FtsK-HerA superfamily DNA packaging ATPase and a protein-primed family B DNA polymerase $[1,8,15]$. These studies have also revealed that genome organization among tectiviruses is highly conserved, in spite of 
low sequence conservation. To thoroughly investigate the relationship of Streptomyces phages WheeHeim and Forthebois to previously described Tectiviridae phages we first analyzed best-reciprocal BLAST hits with Rhodococcus phage Toil, the only phage for which a BLASTP against the NCBI NR database would return significant results. This analysis revealed significant similarity between six genes across these three phages (Table 2). These include the aforementioned major capsid protein, packaging ATPase and DNA polymerase, as well as the PRD1-like membrane DNA delivery protein (duplicated in Streptomyces phages WheeHeim and Forthebois), the entry lysozyme (Toil_gp23) and a hypothetical protein (Toil_gp11). To detect more distant homologs, we conducted HMM-based searches against these three phages and representative phages from previously described tectiviral genera (Pseudomonas virus PRD1, Bacillus virus Bam35 and Gluconobacter phage GC1). These searches confirmed that the three core Tectiviridae proteins (MCP, ATPase and DNA polymerase) are conserved in these three phages and in all previously described Tectiviridae genera. They also identified ample conservation of a virion-associated transglycosylase (SEA_WHEEHEIM_26) known to be involved in PRD1 phage infection [77], and the presence in Streptomyces phages WheeHeim and Forthebois of a homolog of the M23 family metallopeptidase associated with the group of rolling circularly-replicating ssDNA viruses represented by Flavobacterium phage FLiP [8].

Having established distant orthology with proteins in other Tectiviridae genomes, we assessed the apparent similarity in genome organization between Rhodococcus phage Toil and Streptomyces phages WheeHeim and Forthebois in the broader context of Tectiviridae genome architecture. The genome maps displayed in Figure 4 reveal the previously noted structural genome similarity among the three established tectiviral genera [16], and show that this structural similarity extends to the Rhodococcus and Streptomyces phages. All genomes contain a first genomic segment that appears to have switched orientation in multiple instances, with the family B DNA polymerase as its only identifiable conserved element. The second segment, consistently oriented in the forward strand, encompasses the signature double jelly-roll major capsid protein and the DNA packaging ATPase, as well as phage membrane DNA delivery proteins and a lytic transglycosylase. The plot also illustrates the lack of substantial sequence conservation between members the three different genera of the family Tectiviridae. In contrast, and as observed for different tectiviral genera [1,15], Rhodococcus phage Toil and Streptomyces phages WheeHeim and Forthebois display a high degree of sequence similarity (Figure 4). The Average Amino Acid Identity (AAI) between Rhodococcus phage Toil and WheeHeim and Forthebois is, respectively, 35.3\% and $39.1 \%$, suggesting that these three phages are representatives of a single genus. In addition, the large ANI between Streptomyces phages WheeHeim and Forthebois (88.5\%) indicates that they constitute separate species according to the species demarcation criteria of the International Committee on Taxonomy of Viruses (ICTV) [78,79]. 
Table 2. Orthologs of Streptomyces phages WheeHeim and Forthebois proteins.

\begin{tabular}{|c|c|c|c|c|c|c|c|}
\hline Inferred Function & Model & SEA_WHEEHEIM & SEA_FORTHEBOIS & Toil & Bam35 & GC1 [FDJ08] & PRD1 \\
\hline \multirow{6}{*}{ DNA polymerase } & ENOG4108SKE & \multirow{6}{*}{11} & \multirow{6}{*}{11} & \multirow{6}{*}{ gp07 } & \multirow{6}{*}{ ср05 } & \multirow{6}{*}{ gp02 } & \multirow{6}{*}{02} \\
\hline & PF03175.13 & & & & & & \\
\hline & DNAp & & & & & & \\
\hline & ENOG411ENY2 & & & & & & \\
\hline & COG0417 & & & & & & \\
\hline & ENOG4105CQ2 & & & & & & \\
\hline \multirow{7}{*}{ hydrolase } & ENOG4108JJ8 & \multirow{7}{*}{16} & \multirow{7}{*}{16} & \multirow{7}{*}{ gp12 } & \multirow{7}{*}{ ср14 } & \multirow{7}{*}{ gp09 } & \multirow{7}{*}{09} \\
\hline & COG3451 & & & & & & \\
\hline & COG0433 & & & & & & \\
\hline & ENOG411EP64 & & & & & & \\
\hline & STIV_ATP & & & & & & \\
\hline & ENOG4105SBY & & & & & & \\
\hline & ENOG4107MA1 & & & & & & \\
\hline \multirow{3}{*}{ major capsid protein } & Bam_MCP & \multirow{3}{*}{18} & \multirow{3}{*}{18} & \multirow{3}{*}{ gp14 } & \multirow{3}{*}{ сp18 } & \multirow{3}{*}{ gp12 } & \multirow{3}{*}{12} \\
\hline & $\mathrm{MCP}$ & & & & & & \\
\hline & PF09018.11 & & & & & & \\
\hline \multirow{2}{*}{ membrane DNA delivery } & PF11087.8 & 22 & 22 & gp18 & - & gp17 & 16 \\
\hline & PF11087.8 & 28 & 28 & gp18 & - & gp18 & 16 \\
\hline \multirow{8}{*}{ glycosyltransferase } & ENOG4107N29 & \multirow{8}{*}{26} & \multirow{8}{*}{26} & \multirow{8}{*}{ gp23 } & \multirow{8}{*}{-} & \multirow{8}{*}{ gp22 } & \multirow{8}{*}{20} \\
\hline & ENOG41065RS & & & & & & \\
\hline & COG0741 & & & & & & \\
\hline & PF01464.20 & & & & & & \\
\hline & STIV_lysozyme & & & & & & \\
\hline & ENOG41090WR & & & & & & \\
\hline & ENOG4105E4C & & & & & & \\
\hline & ENOG411EP35 & & & & & & \\
\hline
\end{tabular}


Table 2. Cont.

\begin{tabular}{|c|c|c|c|c|c|c|c|}
\hline Inferred Function & Model & SEA_WHEEHEIM & SEA_FORTHEBOIS & Toil & Bam 35 & GC1 [FDJ08] & PRD1 \\
\hline \multirow{3}{*}{ hypothetical protein } & PF01476.20 & \multirow{3}{*}{24} & \multirow{3}{*}{24} & \multirow{3}{*}{ gp20 } & \multirow{3}{*}{-} & \multirow{3}{*}{-} & \multirow{3}{*}{-} \\
\hline & ENOG4108I7Y & & & & & & \\
\hline & COG1652 & & & & & & \\
\hline hypothetical protein & - & 15 & 15 & gp11 & - & - & - \\
\hline \multirow{3}{*}{ ssDNA binding protein } & ENOG4107YH6 & \multirow{3}{*}{13} & \multirow{3}{*}{13} & \multirow{3}{*}{-} & \multirow{3}{*}{-} & \multirow{3}{*}{-} & \multirow{3}{*}{-} \\
\hline & COG0629 & & & & & & \\
\hline & PF00436.25 & & & & & & \\
\hline \multirow{4}{*}{ peptidase } & ENOG4105DR5 & \multirow{4}{*}{31} & \multirow{4}{*}{30} & \multirow{4}{*}{-} & \multirow{4}{*}{-} & \multirow{4}{*}{-} & \multirow{4}{*}{-} \\
\hline & COG0739 & & & & & & \\
\hline & PF01551.22 & & & & & & \\
\hline & peptidase_M23 & & & & & & \\
\hline \multirow{2}{*}{$\begin{array}{l}\text { MazG-like nucleotide } \\
\text { pyrophosphohydrolase }\end{array}$} & ENOG4106A27 & \multirow{2}{*}{3} & \multirow{2}{*}{3} & \multirow{2}{*}{ - } & \multirow{2}{*}{ - } & \multirow{2}{*}{-} & \multirow{2}{*}{ - } \\
\hline & COG1694 & & & & & & \\
\hline \multirow{3}{*}{ LysM-like endolysin } & ENOG4105RG6 & \multirow{3}{*}{36} & \multirow{3}{*}{35} & \multirow{3}{*}{ - } & \multirow{3}{*}{ - } & \multirow{3}{*}{-} & \\
\hline & COG3023 & & & & & & - \\
\hline & PF01510.25 & & & & & & \\
\hline membrane protein & ENOG4106BPY & 4 & 4 & - & - & - & - \\
\hline & ENOG4105K4H & & & & & & \\
\hline NlpC family hydrolase & COG0791 & - & - & gp26 & - & - & - \\
\hline & PF00877.19 & & & & & & \\
\hline endolysin & ENOG4105SQZ & - & - & gp31 & - & - & - \\
\hline & PF13539.6 & & & & & & \\
\hline
\end{tabular}

Orthologs among Rhodococcus phage Toil and Streptomyces phages WheeHeim and Forthebois were determined as best-reciprocal BLAST hits. Only genes with significant $(e$-value $<1 \times$ $10^{-5}$ ) hmmscan/hmmsearch matches to PFAM, EGGNOG, COG and previously published models are reported. Proteins matching the same model were considered to belong to the same orthologous group. An extended version of this table containing the search e-values is available in Table S3. 


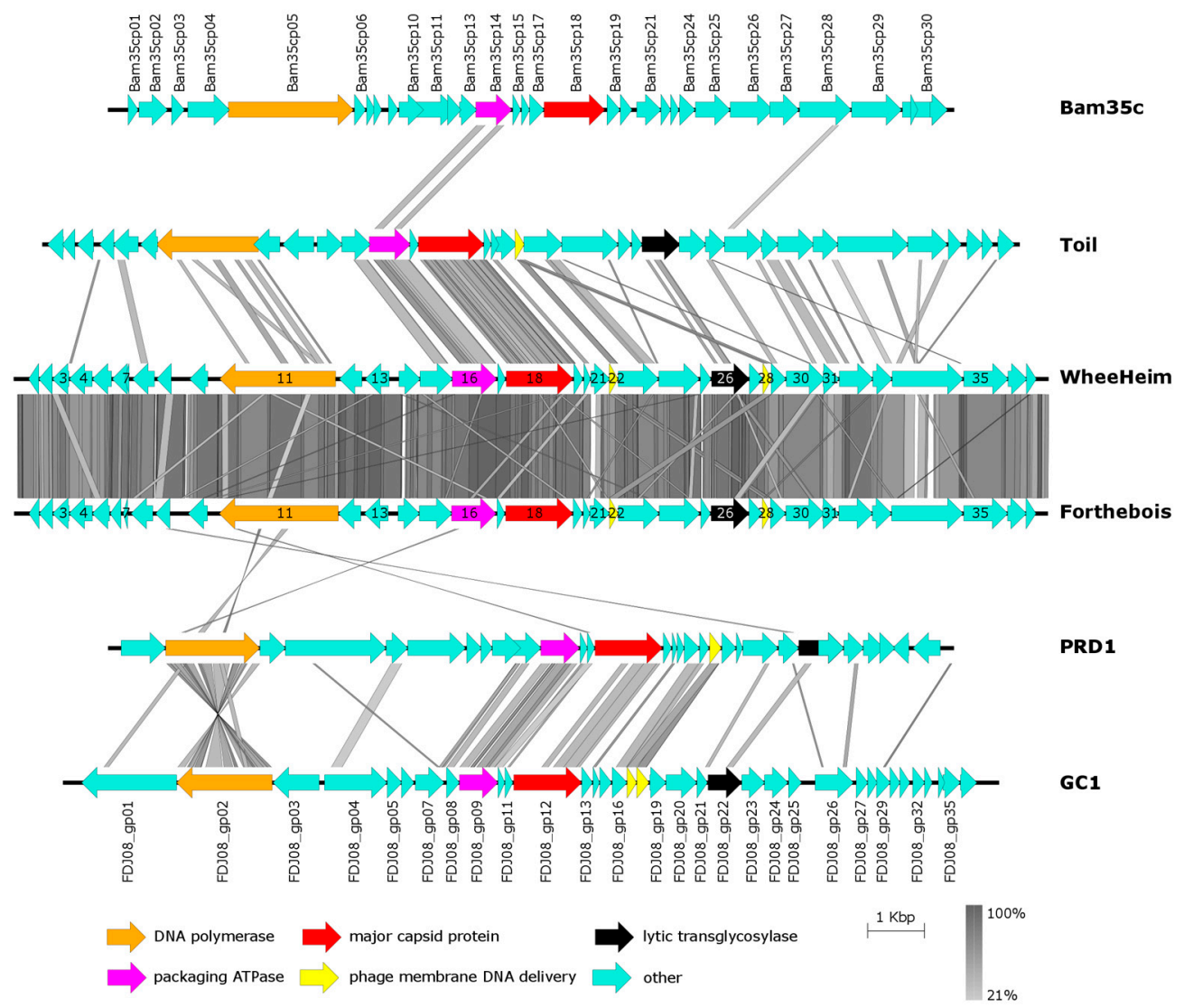

Figure 4. Genome maps of Rhodococcus phage Toil, Streptomyces phages WheeHeim and Forthebois, Gluconobacter phage GC1, Pseudomonas virus PRD1 and Bacillus virus Bam35. Colored arrows indicate genes. Vertical bars indicate percent amino acid identity from pairwise tBLASTX comparisons on a grey scale. For genes with assigned function in Table 1, gene numbers for Streptomyces phages WheeHeim and Forthebois are superimposed on the corresponding colored arrows.

To more rigorously ascertain whether Rhodococcus phage Toil and Streptomyces phages WheeHeim and Forthebois define a novel genus in the family Tectiviridae, we performed Bayesian phylogenetic inference with the aligned sequences of the three conserved Tectiviridae proteins (MCP, ATPase and DNA polymerase), as well as bootstrapped minimal evolution phylogenetic inference with intergenomic protein sequence distances inferred from pair-wise genome-wide tBLASTX. The independently inferred phylogenies (Figure 5) consistently and robustly place Rhodococcus phage Toil and Streptomyces phages WheeHeim and Forthebois in a cohesive cluster similarly distant from the previously reported genera within the family Tectiviridae as these are from each other, strongly supporting their classification as a new genus within the Tectiviridae. Following the established convention for the family, we have tentatively named this novel genus Deltatectivirus. The inferred phylogenies also conclusively cluster the Alphatectivirus and Gammatectivirus genera together, suggesting that these two groups arose from a common ancestor. The phylogenies indicate that the common ancestor of extant Tectiviridae species emerged at least one billion years ago, prior to the split between Gram-positive and Gram-negative bacteria $[80,81]$. The consistency between single-gene and whole genome phylogenies (Figure 5) and the conserved genome structure (Figure 4) suggests that tectiviruses have since diversified along with their hosts, rather than evolving through lateral gene transfer events enabling the swap of spike complexes to target novel hosts. 

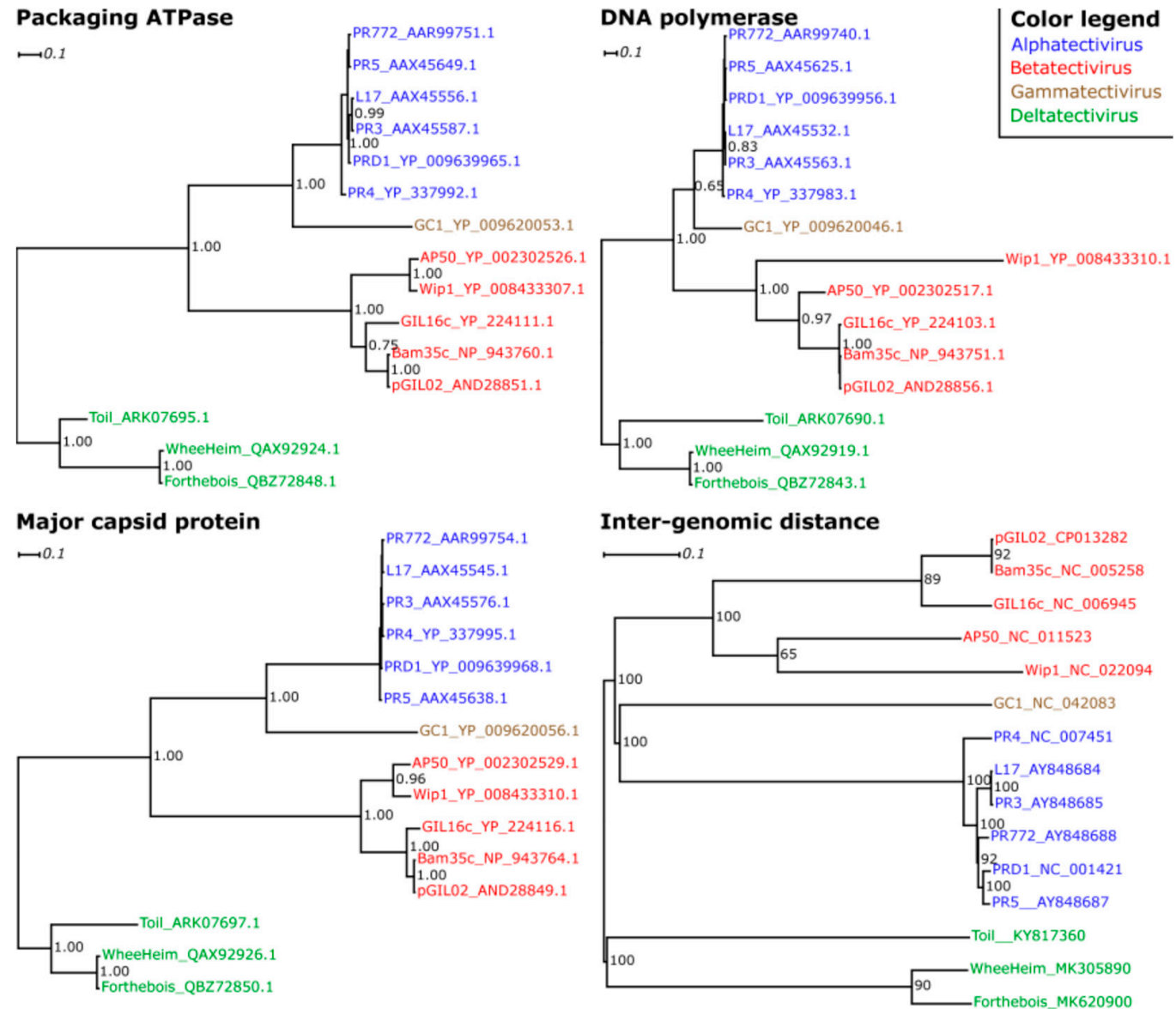

Figure 5. Phylogenetic trees resulting from Bayesian inference on multiple sequence alignments of the packaging ATPase, the DNA polymerase and the major capsid protein sequences, and from minimal evolution inference on BLAST-derived inter-genomic distances. Only support values above 0.5 posterior probability or $50 \%$ bootstrap support are shown. Trees were rooted arbitrarily for display purposes. Colors denote the previously described Tectiviridae genera (Alphatectivirus, blue; Betatectivirus, red; Gammatectivirus, brown) as well as the proposed novel genus Deltatectivirus (green).

\section{Conclusions}

This work describes the morphological and genomic characterization of two novel phages infecting Streptomyces scabiei. Based on both morphological and genomic characteristics, we have established that Streptomyces phages WheeHeim and Forthebois should belong to the Tectiviridae family, wherein they could conform a distinct genus, tentatively named Deltatectivirus, that would include also the recently reported Rhodococcus phage Toil. Like other Gram-positive infecting tectiviruses, these phages display a lysogenic cycle, but the mechanism by which they mediate transition to the lytic cycle remains to be elucidated. This work also identifies for the first time the presence of a collar-like structure in the protruding nanotubes of tectiviruses, and provides strong support to the notion that the Tectiviridae define a family of bacteriophages with cohesive genome structure that originated well before the split of their Gram-positive and Gram-negative hosts.

Supplementary Materials: The following are available online at http://www.mdpi.com/1999-4915/11/12/1134/s1.

Author Contributions: Conceptualization, I.E. and S.M.C.; methodology, I.E. and S.M.C.; software, I.E.; validation, I.E., S.M.C. and T.N.d.; formal analysis, I.E.; investigation, I.E., S.M.C., A.H., G.M., N.K., S.P. and T.N.d.; resources, S.M.C., A.H., G.M., N.K. and S.P.; data curation, I.E. and S.M.C.; writing-original draft preparation, I.E.; writing-review and editing, I.E., S.M.C. and T.N.d.; visualization, I.E., S.M.C. and T.N.d.; supervision, I.E. and S.M.C.; funding acquisition, S.M.C. 
Funding: Research reported in this publication was supported by the National Institute of General Medical Sciences of the National Institutes of Health under Award Numbers TL4GM118989, UL1GM118988, and RL5GM118987. The content is solely the responsibility of the authors and does not necessarily represent the official views of the National Institutes of Health. This work was also supported by the UMBC Department of Biological Sciences and the Howard Hughes Medical Institute SEA-PHAGES program.

Acknowledgments: The authors wish to thank Ralph Murphy and Joshua Wilhide for their excellent technical support. The authors also wish to thank Graham F. Hatfull, Deborah Jacobs-Sera, Welkin H. Pope, Daniel R. Russell, Steven G. Cresawn and the Howard Hughes Medical Institute SEA-PHAGES program for their support. The authors wish to thank the members of STEM BUILD at UMBC Cohort 2 (Jessica Braun, Teodora Danaila, Nick Emelio, Sharanja Mathyvannan, Kollin Miner, Rushika Nayak, Caroline Norman, Vivi Tran and Jie Wang) for the initial genomic characterization of Streptomyces phage WheeHeim. The authors also want to express their gratitude to Nicola Abrescia, Nadine Fornelos and Matti Jalasvuori for insightful discussions on the morphological interpretation of TEM data. Imaging work was performed at the Keith R. Porter Facility, UMBC and mass spectrometry work was performed by Dr. Yue Li at the Mass Spectrometry Facility, University of Maryland, College Park (UMD).

Conflicts of Interest: The authors declare no conflict of interest. The funders had no role in the design of the study; in the collection, analyses, or interpretation of data; in the writing of the manuscript, or in the decision to publish the results.

\section{References}

1. Saren, A.-M.; Ravantti, J.J.; Benson, S.D.; Burnett, R.M.; Paulin, L.; Bamford, D.H.; Bamford, J.K.H. A snapshot of viral evolution from genome analysis of the tectiviridae family. J. Mol. Biol. 2005, 350, 427-440. [CrossRef] [PubMed]

2. Mäntynen, S.; Sundberg, L.-R.; Oksanen, H.M.; Poranen, M.M. Half a century of research on membrane-containing bacteriophages: Bringing new concepts to modern virology. Viruses 2019, 11, 76. [CrossRef] [PubMed]

3. Sokolova, A.; Malfois, M.; Caldentey, J.; Svergun, D.I.; Koch, M.H.; Bamford, D.H.; Tuma, R. Solution structure of bacteriophage PRD1 vertex complex. J. Biol. Chem. 2001, 276, 46187-46195. [CrossRef] [PubMed]

4. Peralta, B.; Gil-Carton, D.; Castaño-Díez, D.; Bertin, A.; Boulogne, C.; Oksanen, H.M.; Bamford, D.H.; Abrescia, N.G.A. Mechanism of membranous tunnelling nanotube formation in viral genome delivery. PLoS Biol. 2013, 11, e1001667. [CrossRef]

5. Santos-Pérez, I.; Oksanen, H.M.; Bamford, D.H.; Goñi, F.M.; Reguera, D.; Abrescia, N.G.A. Membrane-assisted viral DNA ejection. Biochim. Biophys. Acta Gen. Subj. 2017, 1861, 664-672. [CrossRef]

6. Grahn, A.M.; Daugelavičius, R.; Bamford, D.H. Sequential model of phage PRD1 DNA delivery: Active involvement of the viral membrane. Mol. Microbiol. 2002, 46, 1199-1209. [CrossRef]

7. Kauffman, K.M.; Hussain, F.A.; Yang, J.; Arevalo, P.; Brown, J.M.; Chang, W.K.; VanInsberghe, D.; Elsherbini, J.; Sharma, R.S.; Cutler, M.B.; et al. A major lineage of non-tailed dsDNA viruses as unrecognized killers of marine bacteria. Nature 2018, 554, 118-122. [CrossRef]

8. Yutin, N.; Bäckström, D.; Ettema, T.J.G.; Krupovic, M.; Koonin, E.V. Vast diversity of prokaryotic virus genomes encoding double jelly-roll major capsid proteins uncovered by genomic and metagenomic sequence analysis. Virol. J. 2018, 15, 67. [CrossRef]

9. Adriaenssens, E.M.; Wittmann, J.; Kuhn, J.H.; Turner, D.; Sullivan, M.B.; Dutilh, B.E.; Jang, H.B.; van Zyl, L.J.; Klumpp, J.; Lobocka, M.; et al. Taxonomy of prokaryotic viruses: 2017 update from the ICTV Bacterial and Archaeal Viruses Subcommittee. Arch. Virol. 2018, 163, 1125-1129. [CrossRef]

10. Coetzee, W.F.; Bekker, P.J. Pilus-specific, lipid-containing bacteriophages PR4 and PR772: Comparison of physical characteristics of genomes. J. Gen. Virol. 1979, 45, 195-200. [CrossRef]

11. Bamford, D.H.; Ziedaite, G. Tectivirus, Tectiviridae. In The Springer Index of Viruses; Tidona, C., Darai, G., Eds.; Springer: New York, NY, USA, 2011; pp. 1841-1846.

12. Verheust, C.; Fornelos, N.; Mahillon, J. GIL16, a new Gram-positive tectiviral phage related to the Bacillus thuringiensis GIL01 and the Bacillus cereus pBClin15 elements. J. Bacteriol. 2005, 187, 1966-1973. [CrossRef] [PubMed]

13. Sozhamannan, S.; McKinstry, M.; Lentz, S.M.; Jalasvuori, M.; McAfee, F.; Smith, A.; Dabbs, J.; Ackermann, H.-W.; Bamford, J.K.H.; Mateczun, A.; et al. Molecular characterization of a variant of Bacillus anthracis-specific phage AP50 with improved bacteriolytic activity. Appl. Environ. Microbiol. 2008, 74, 6792-6796. [CrossRef] [PubMed] 
14. Schuch, R.; Fischetti, V.A. The secret life of the anthrax agent Bacillus anthracis: Bacteriophage-mediated ecological adaptations. PLoS ONE 2009, 4, e6532. [CrossRef] [PubMed]

15. Jalasvuori, M.; Koskinen, K. Extending the hosts of Tectiviridae into four additional genera of Gram-positive bacteria and more diverse Bacillus species. Virology 2018, 518, 136-142. [CrossRef]

16. Philippe, C.; Krupovic, M.; Jaomanjaka, F.; Claisse, O.; Petrel, M.; le Marrec, C. Bacteriophage GC1, a novel tectivirus infecting Gluconobacter cerinus, an acetic acid bacterium associated with wine-making. Viruses 2018, 10, 39. [CrossRef]

17. Gill, J.J.; Wang, B.; Sestak, E.; Young, R.; Chu, K.-H. Characterization of a novel tectivirus Phage Toil and its potential as an agent for biolipid extraction. Sci. Rep. 2018, 8, 1062. [CrossRef]

18. Jordan, T.C.; Burnett, S.H.; Carson, S.; Caruso, S.M.; Clase, K.; DeJong, R.J.; Dennehy, J.J.; Denver, D.R.; Dunbar, D.; Elgin, S.C.R.; et al. A broadly implementable research course in phage discovery and genomics for first-year undergraduate students. MBio 2014, 5, e01051-13. [CrossRef]

19. Hanauer, D.I.; Graham, M.J.; SEA-PHAGES; Betancur, L.; Bobrownicki, A.; Cresawn, S.G.; Garlena, R.A.; Jacobs-Sera, D.; Kaufmann, N.; Pope, W.H.; et al. An inclusive Research Education Community (iREC): Impact of the SEA-PHAGES program on research outcomes and student learning. Proc. Natl. Acad. Sci. USA 2017, 114, 13531-13536. [CrossRef]

20. LaCourse, W.R.; Sutphin, K.L.; Ott, L.E.; Maton, K.I.; McDermott, P.; Bieberich, C.; Farabaugh, P.; Rous, P. Think 500, not 50! A scalable approach to student success in STEM. BMC Proc. 2017, 11, 24. [CrossRef]

21. Blocker, D.; Koert, M.; Mattson, C.; Patel, H.; Patel, P.; Patel, R.; Paudel, H.; 2017 UMBC Phage Hunters; Erill, I.; Caruso, S.M. Complete genome sequences of six BI cluster Streptomyces bacteriophages, HotFries, Moozy, Rainydai, RavenPuff, Scap1, and SenditCS. Microbiol. Resour. Announc. 2018, 7, e00993-18. [CrossRef]

22. Loria, R.; Kers, J.; Joshi, M. Evolution of plant pathogenicity in Streptomyces. Annu. Rev. Phytopathol. 2006, 44, 469-487. [CrossRef] [PubMed]

23. Waterer, D. Impact of high soil $\mathrm{pH}$ on potato yields and grade losses to common scab. Can. J. Plant Sci. 2002, 82, 583-586. [CrossRef]

24. Bischoff, V.; Cookson, S.J.; Wu, S.; Scheible, W.-R. Thaxtomin A affects CESA-complex density, expression of cell wall genes, cell wall composition, and causes ectopic lignification in Arabidopsis thaliana seedlings. J. Exp. Bot. 2009, 60, 955-965. [CrossRef] [PubMed]

25. McKenna, F.; El-Tarabily, K.; Hardy, G.S.J.; Dell, B. Novel in vivo use of a polyvalent Streptomyces phage to disinfest Streptomyces scabies-infected seed potatoes. Plant pathol. 2001, 50, 666-675. [CrossRef]

26. el-Sayed, e.A.; el-Didamony, G.; Mansour, K. Isolation and characterization of two types of actinophage infecting Streptomyces scabies. Folia Microbiol. 2001, 46, 519-526. [CrossRef] [PubMed]

27. Ashfield-Crook, N.R.; Woodward, Z.; Soust, M.; Kurtböke, D.İ. Assessment of the detrimental impact of polyvalent streptophages intended to be used as biological control agents on beneficial soil streptoflora. Curr. Microbiol. 2018, 75, 1589-1601. [CrossRef] [PubMed]

28. Goyer, C. Isolation and characterization of phages Stsc1 and Stsc3 infecting Streptomyces scabiei and their potential as biocontrol agents. Can. J. Plant Pathol. 2005, 27, 210-216. [CrossRef]

29. Kieser, T.; Bibb, M.J.; Buttner, M.J.; Chater, K.F.; Hopwood, D.A. Practical Streptomyces Genetics; The John Innes Foundation: Norwich, UK, 2000; ISBN 978-0-7084-0623-6.

30. Sarkis, G.J.; Hatfull, G.F. Mycobacteriophages. Methods Mol. Biol. 1998, 101, 145-173.

31. Jacobs-Sera, D.; Marinelli, L.J.; Bowman, C.; Broussard, G.W.; Guerrero Bustamante, C.; Boyle, M.M.; Petrova, Z.O.; Dedrick, R.M.; Pope, W.H.; Science Education Alliance Phage Hunters Advancing Genomics and Evolutionary Science (SEA-PHAGES) Program; et al. On the nature of mycobacteriophage diversity and host preference. Virology 2012, 434, 187-201. [CrossRef]

32. Pope, W.H.; Jacobs-Sera, D. Annotation of bacteriophage genome sequences using DNA Master: An overview. Methods Mol. Biol. 2018, 1681, 217-229.

33. Laslett, D.; Canback, B. ARAGORN, a program to detect tRNA genes and tmRNA genes in nucleotide sequences. Nucleic Acids Res. 2004, 32, 11-16. [CrossRef] [PubMed]

34. Besemer, J.; Lomsadze, A.; Borodovsky, M. GeneMarkS: A self-training method for prediction of gene starts in microbial genomes. Implications for finding sequence motifs in regulatory regions. Nucleic Acids Res. 2001, 29, 2607-2618. [CrossRef] [PubMed] 
35. Chan, P.P.; Lowe, T.M. tRNAscan-SE: Searching for tRNA genes in genomic sequences. Methods Mol. Biol. 2019, 1962, 1-14. [PubMed]

36. Altschul, S.F.; Madden, T.L.; Schaffer, A.A.; Zhang, J.; Zhang, Z.; Miller, W.; Lipman, D.J. Gapped BLAST and PSI-BLAST: A new generation of protein database search programs. Nucleic Acids Res. 1997, 25, 3389-3402. [CrossRef] [PubMed]

37. Söding, J.; Biegert, A.; Lupas, A.N. The HHpred interactive server for protein homology detection and structure prediction. Nucleic Acids Res. 2005, 33, W244-W248. [CrossRef]

38. Pope, W.H.; Jacobs-Sera, D.; Russell, D.A.; Rubin, D.H.F.; Kajee, A.; Msibi, Z.N.P.; Larsen, M.H.; Jacobs, W.R.; Lawrence, J.G.; Hendrix, R.W.; et al. Genomics and proteomics of Mycobacteriophage Patience, an accidental tourist in the Mycobacterium neighborhood. MBio 2014, 5, e02145-14. [CrossRef]

39. Kiliç, S.; White, E.R.; Sagitova, D.M.; Cornish, J.P.; Erill, I. CollecTF: A database of experimentally validated transcription factor-binding sites in Bacteria. Nucleic Acids Res. 2014, 42, D156-D160. [CrossRef]

40. Bhargava, N.; Erill, I. xFITOM: A generic GUI tool to search for transcription factor binding sites. Bioinformation 2010, 5, 49-51. [CrossRef]

41. Rodriguez-R, L.M.; Konstantinidis, K.T. Bypassing cultivation to identify bacterial species. Microbe 2014, 9, 111-118. [CrossRef]

42. Pedulla, M.L.; Ford, M.E.; Houtz, J.M.; Karthikeyan, T.; Wadsworth, C.; Lewis, J.A.; Jacobs-Sera, D.; Falbo, J.; Gross, J.; Pannunzio, N.R.; et al. Origins of highly mosaic mycobacteriophage genomes. Cell 2003, 113, 171-182. [CrossRef]

43. Vitale, R.; Roine, E.; Bamford, D.H.; Corcelli, A. Lipid fingerprints of intact viruses by MALDI-TOF/mass spectrometry. Biochim. Biophys. Acta 2013, 1831, 872-879. [CrossRef] [PubMed]

44. Galperin, M.Y.; Makarova, K.S.; Wolf, Y.I.; Koonin, E.V. Expanded microbial genome coverage and improved protein family annotation in the COG database. Nucleic Acids Res. 2015, 43, D261-D269. [CrossRef] [PubMed]

45. Dibrova, D.V.; Konovalov, K.A.; Perekhvatov, V.V.; Skulachev, K.V.; Mulkidjanian, A.Y. COGcollator: A web server for analysis of distant relationships between homologous protein families. Biol. Direct 2017, 12, 29. [CrossRef] [PubMed]

46. Finn, R.D.; Coggill, P.; Eberhardt, R.Y.; Eddy, S.R.; Mistry, J.; Mitchell, A.L.; Potter, S.C.; Punta, M.; Qureshi, M.; Sangrador-Vegas, A.; et al. The Pfam protein families database: Towards a more sustainable future. Nucleic Acids Res. 2016, 44, D279-D285. [CrossRef]

47. Huerta-Cepas, J.; Szklarczyk, D.; Forslund, K.; Cook, H.; Heller, D.; Walter, M.C.; Rattei, T.; Mende, D.R.; Sunagawa, S.; Kuhn, M.; et al. eggNOG 4.5: A hierarchical orthology framework with improved functional annotations for eukaryotic, prokaryotic and viral sequences. Nucleic Acids Res. 2016, 44, D286-D293. [CrossRef]

48. Eddy, S.R. Accelerated Profile HMM Searches. PLoS Comput. Biol 2011, 7, e1002195. [CrossRef]

49. NCBI Resource Coordinators. Database resources of the National Center for Biotechnology Information. Nucleic Acids Res. 2017, 45, D12-D17. [CrossRef]

50. Moretti, S.; Armougom, F.; Wallace, I.M.; Higgins, D.G.; Jongeneel, C.V.; Notredame, C. The M-Coffee web server: A meta-method for computing multiple sequence alignments by combining alternative alignment methods. Nucleic Acids Res. 2007, 35, W645-W648. [CrossRef]

51. Castresana, J. Selection of conserved blocks from multiple alignments for their use in phylogenetic analysis. Mol. Biol. Evol. 2000, 17, 540-552. [CrossRef]

52. Ronquist, F.; Huelsenbeck, J.P. MrBayes 3: Bayesian phylogenetic inference under mixed models. Bioinformatics 2003, 19, 1572-1574. [CrossRef]

53. Huson, D.H.; Richter, D.C.; Rausch, C.; Dezulian, T.; Franz, M.; Rupp, R. Dendroscope: An interactive viewer for large phylogenetic trees. BMC Bioinform. 2007, 8, 460. [CrossRef] [PubMed]

54. Meier-Kolthoff, J.P.; Göker, M. VICTOR: Genome-based phylogeny and classification of prokaryotic viruses. Bioinformatics 2017, 33, 3396-3404. [CrossRef] [PubMed]

55. Meier-Kolthoff, J.P.; Auch, A.F.; Klenk, H.-P.; Göker, M. Genome sequence-based species delimitation with confidence intervals and improved distance functions. BMC Bioinform. 2013, 14, 60. [CrossRef] [PubMed]

56. Lefort, V.; Desper, R.; Gascuel, O. FastME 2.0: A comprehensive, accurate, and fast distance-based phylogeny inference program. Mol. Biol. Evol. 2015, 32, 2798-2800. [CrossRef] [PubMed] 
57. Lambert, D.; Loria, R. Streptomyces scabies sp. nov., nom. rev. Int. J. Syst. Evol. Microbiol. 1989, 39, $387-392$. [CrossRef]

58. Russell, D.A.; Hatfull, G.F. PhagesDB: The actinobacteriophage database. Bioinformatics 2017, 33, 784-786. [CrossRef]

59. Bouchek-Mechiche, K.; Gardan, L.; Andrivon, D.; Normand, P. Streptomyces turgidiscabies and Streptomyces reticuliscabiei: One genomic species, two pathogenic groups. Int. J. Syst. Evol. Microbiol. 2006, 56, 2771-2776. [CrossRef]

60. Laurinmäki, P.A.; Huiskonen, J.T.; Bamford, D.H.; Butcher, S.J. Membrane proteins modulate the bilayer curvature in the bacterial virus Bam35. Structure 2005, 13, 1819-1828. [CrossRef]

61. Yu, M.X.; Slater, M.R.; Ackermann, H.-W. Isolation and characterization of Thermus bacteriophages. Arch. Virol. 2006, 151, 663-679. [CrossRef]

62. Jalasvuori, M.; Palmu, S.; Gillis, A.; Kokko, H.; Mahillon, J.; Bamford, J.K.H.; Fornelos, N. Identification of five novel tectiviruses in Bacillus strains: Analysis of a highly variable region generating genetic diversity. Res. Microbiol. 2013, 164, 118-126. [CrossRef]

63. Vegge, C.S.; Brøndsted, L.; Neve, H.; Mc Grath, S.; van Sinderen, D.; Vogensen, F.K. Structural Characterization and assembly of the distal tail structure of the temperate lactococcal Bacteriophage TP901-1. J. Bacteriol. 2005, 187, 4187-4197. [CrossRef] [PubMed]

64. Fokine, A.; Zhang, Z.; Kanamaru, S.; Bowman, V.D.; Aksyuk, A.A.; Arisaka, F.; Rao, V.B.; Rossmann, M.G. The molecular architecture of the bacteriophage T4 neck. J. Mol. Biol. 2013, 425, 1731-1744. [CrossRef] [PubMed]

65. Xu, J.; Wang, D.; Gui, M.; Xiang, Y. Structural assembly of the tailed bacteriophage $\phi 29$. Nat. Commun. 2019, 10, 2366. [CrossRef] [PubMed]

66. Ito, J. Bacteriophage phi29 terminal protein: Its association with the $5^{\prime}$ termini of the phi29 genome. J. Virol. 1978, 28, 895-904. [PubMed]

67. Yoon, S.-H.; Ha, S.-M.; Lim, J.; Kwon, S.; Chun, J. A large-scale evaluation of algorithms to calculate average nucleotide identity. Antonie Van Leeuwenhoek 2017, 110, 1281-1286. [CrossRef] [PubMed]

68. Zhang, J.; Inouye, M. MazG, a nucleoside triphosphate pyrophosphohydrolase, interacts with Era, an essential GTPase in Escherichia coli. J. Bacteriol. 2002, 184, 5323-5329. [CrossRef]

69. Oliveira, H.; Melo, L.D.R.; Santos, S.B.; Nóbrega, F.L.; Ferreira, E.C.; Cerca, N.; Azeredo, J.; Kluskens, L.D. Molecular aspects and comparative genomics of bacteriophage endolysins. J. Virol. 2013, 87, 4558-4570. [CrossRef]

70. Davis, T.N.; Muller, E.D.; Cronan, J.E. The virion of the lipid-containing bacteriophage PR4. Virology 1982, 120, 287-306. [CrossRef]

71. Laurinavicius, S.; Käkelä, R.; Somerharju, P.; Bamford, D.H. Phospholipid molecular species profiles of tectiviruses infecting Gram-negative and Gram-positive hosts. Virology 2004, 322, 328-336. [CrossRef]

72. Laurinavicius, S.; Bamford, D.H.; Somerharju, P. Transbilayer distribution of phospholipids in bacteriophage membranes. Biochim. Biophys. Acta 2007, 1768, 2568-2577. [CrossRef]

73. Gillis, A.; Mahillon, J. Prevalence, genetic diversity, and host range of tectiviruses among members of the Bacillus cereus group. Appl. Environ. Microbiol. 2014, 80, 4138-4152. [CrossRef] [PubMed]

74. Fornelos, N.; Bamford, J.K.H.; Mahillon, J. Phage-borne factors and host LexA regulate the lytic switch in Phage GIL01. J. Bacteriol. 2011, 193, 6008-6019. [CrossRef] [PubMed]

75. Chen, Z.; Zhong, L.; Shen, M.; Fang, P.; Qin, Z. Characterization of Streptomyces plasmid-phage $p F P 4$ and its evolutionary implications. Plasmid 2012, 68, 170-178. [CrossRef] [PubMed]

76. Pourcel, C.; Midoux, C.; Vergnaud, G.; Latino, L. A carrier state is established in Pseudomonas aeruginosa by phage LeviOr01, a newly isolated ssRNA levivirus. J. Gen. Virol. 2017, 98, 2181-2189. [CrossRef] [PubMed]

77. Rydman, P.S.; Bamford, D.H. Bacteriophage PRD1 DNA entry uses a viral membrane-associated transglycosylase activity. Mol. Microbiol. 2000, 37, 356-363. [CrossRef]

78. Díaz-Pendón, J.A.; Cañizares, M.C.; Moriones, E.; Bejarano, E.R.; Czosnek, H.; Navas-Castillo, J. Tomato yellow leaf curl viruses: Ménage à trois between the virus complex, the plant and the whitefly vector. Mol. Plant. Pathol. 2010, 11, 441-450. [CrossRef] [PubMed]

79. Fauquet, C.; Fargette, D. International Committee on Taxonomy of Viruses and the 3142 unassigned species. Virol. J. 2005, 2, 64. [CrossRef] 
80. Sheridan, P.P.; Freeman, K.H.; Brenchley, J.E. Estimated minimal divergence times of the major bacterial and archaeal phyla. Geomicrobiol. J. 2003, 20, 1-14. [CrossRef]

81. Battistuzzi, F.U.; Feijao, A.; Hedges, S.B. A genomic timescale of prokaryote evolution: Insights into the origin of methanogenesis, phototrophy, and the colonization of land. BMC Evol. Biol. 2004, 4, 44. [CrossRef]

(C) 2019 by the authors. Licensee MDPI, Basel, Switzerland. This article is an open access article distributed under the terms and conditions of the Creative Commons Attribution (CC BY) license (http://creativecommons.org/licenses/by/4.0/). 